REGE

25,1

2

Received 21 September 2017 Revised 3 October 2017 15 October 2017 Accepted 26 October 2017

\section{THINKBOX The issue of gender and race in career progress and labor market}

\author{
Sandra Maria Cerqueira da Silva \\ Feira de Santana State University, Feira de Santana, Brazil, and \\ Angela Lucas \\ Centro Universitário da FEI, São Paulo, Brazil
}

\begin{abstract}
Purpose - The text is the result of research carried out at undergraduate and post-graduate levels. This think-box corresponds to a collection of ideas and reflections debated in a roundtable that discussed issues related to access and career limitations for women, especially for black women. In this sense, the purpose of this paper is to present, analytically, data that demonstrate the unequal conditions by gender and race.

Design/methodology/approach - The selected approach was qualitative in a critical perspective.

Findings - The discussion elicits important social markers to establish difference, and thereby promote exclusion. Reflection on these issues needs to go beyond academic boundaries and reach the business community, perhaps worldwide, sensitizing them to the urgent need to revise biased methods and procedures that are crystallized. It is necessary to create conditions for a more balanced and humane look at women, especially black women. And, in this way ensure fairness in the treatment of people in all aspects, especially in educational spaces and the labor market. Research limitations/implications - The difficulty in identifying some systematized data limits the condition of broadening our view to points that have been discussed in the text, such as where are the 6 percent of black executive women.

Practical implications - It is hoped that this paper may elicit reflections on the current social exclusionary context, and subsidize practices on a more equitable basis observing gender and race.

Social implications - Socially speaking, it is hoped that this discussion could guide actions to eliminate or reduce the gap, mainly through specific public policies to address the issues of women in Brazil.

Originality/value - It is the parallel discussion of gender and race in the business sector, where the subjects were scarcely explored, and the critical theory was used as a basis of analysis.
\end{abstract}

Keywords Gender, Race, Labour market, Woman

Paper type Viewpoint

This pensata results from research carried out initially in undergraduate and later in graduate studies. The text comprises a collection of ideas and reflections discussed at the roundtable that took place on March 22 of the current year.

To deal with "The Issue of Gender and Race in Career Progress and Labor Market" means to expand a discussion that involves complexities and responsibility, given the various intersections involved. Much has been done on the subject, although in limited spaces, and almost always for the same audience. Due to the few and slow advances, we argue about the urgency to extend the discussions on women's living conditions in Brazil, as well as on their professional situation, or rather, on the non-access situation, as described below.

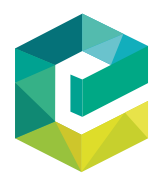

Revista de Gestão Vol. 25 No. 1,2018 pp. $2-8$ Emerald Publishing Limited 2177-8736 DOI 10.1108/REGE-11-2017-006

\section{Data on inequalities of gender and race}

Using the historical series from 1995 to 2015 of the National Survey by Household Sample (PNAD), conducted by the Brazilian Institute of Geography and Statistics (BGE), women's

\footnotetext{
(C) Sandra Maria Cerqueira da Silva and Angela Lucas. Published in Revista de Gestão. Published by Emerald Publishing Limited. This article is published under the Creative Commons Attribution (CC BY 4.0) licence. Anyone may reproduce, distribute, translate and create derivative works of this article (for both commercial and non-commercial purposes), subject to full attribution to the original publication and authors. The full terms of this licence may be seen at http://creativecommons.org/licences/by/4.0/legalcode
} 
working time are, on average, 7.5 hours longer than men's, per week. This was shown in a 2017 research by the Institute of Applied Economic Research (IPEA), which points that "in 2015, women's average total working time was 53.6 hours, while men's was 46.1 hours." When it comes to unpaid activities, "more than 90 percent of women reported doing domestic activities - a proportion that remained almost unchanged over 20 years, as well as that of men (around 50 percent)." In other words, employed women continue to be responsible for the unpaid domestic labor, which leads to the so-called double, or even triple journey.

We are in the middle of 2017, but difficulties that existed centuries ago still remain. So, our motivation here is to highlight the challenges that women face in the labor market, simply for being women. An example is the fact that men have higher wages than women throughout the world. In Brazil, "the higher women's income, the smaller the proportion of those who declared to do household chores - among those with income of one minimum wage or less, 94 percent were engaged in household tasks, against 79.5 percent among women with income above eight minimum wages. Men are in an opposite situation. The proportion of those who declared doing housework is higher among men with the highest income: 57 percent of those who earned between five and eight minimum wages carried out these tasks, a percentage that falls to 49 percent among those with lower income." In some areas, the difference exceeds 50 percent of the value received by their counterparts, and this distinction starts at the beginning of the career. Still according to "A Picture of Gender and Race Inequalities" Instituto de Pesquisa Econômica Aplicada (IPEA, 2011), to exercise a paid activity does not affect the responsibility for domestic activities assumed by women, although it reduces the amount of hours devoted to them.

According to a research published by Grant Thornton Brasil (2017), Brazil is considered one of the worst countries regarding women's participation in leadership positions. The country neither has good references on matters of racial nor wage equality, besides female leadership.

According to the IPEA study (2017), which used indicators from IBGE/PNAD, although proportionally the income of black women was the most appreciated between 1995 and 2015 (80 percent), while that of white males grew the least (11 percent), the payment scale remained unchanged throughout the historical series. Therefore, white men continue to have the best income, followed by white women, black men and black women. The difference in the unemployment rate also deserves register: in 2015, female proportion was 11.6 percent, while for men it was 7.8 percent. In the case of black women, it reached 13.3 percent (and 8.5 percent for black men). Only 11.5 percent of the top managers in the 50 largest companies in Brazil are women, although they represent more than half of the people with higher education degrees and have more years of study.

This scenario has been formed over the years through discriminatory behaviors internalized by daily social constructions. To achieve it, "truths" have been imposed, such as ascribing to women the responsibility for home and family care.

\section{Care, motherhood and career: vocation and limitations}

An important milestone for keeping gender and race inequalities occurs at the beginning of professional qualification; when starting undergraduate studies, women are sometimes submitted to a considerable set of prejudiced "jokes." Few people, with a strong family base that ensures them self-esteem and safety, are able to better cope with these potential constraints. At the other end, there are cases where the assaulted person thinks: if all the people around me understand that this is "normal," then if there is something wrong, it must be with me, not with them. And they shut up, silencing their anguish, and continue to suffer daily minor aggressions. This is possible because there is hardly any room for debates about prejudice. Thus, by the time they enter the labor market, any doubts that still remain about the existence of discriminatory processes become clear. 
REGE 25,1

Differences are marked and painful. Lombardi (2017) describes, for example, what happens in engineering:

Subjected to peculiar organization and working conditions since the beginning of their careers, construction engineers face a rude and disrespectful treatment from colleagues and bosses as an integral part of their practical training. In general, these patterns of conduct are accepted as normal and not as bullying. For women engineers, there is also gender harassment, through explicit situations of discrimination and violence, which tend to negatively affect their higher insertion in construction sites.

Another outstanding moment for women is when the first pregnancy coincides with the time of professional positioning. Go on with the career or invest in motherhood? This question is not simple at all, but, in general, it looks like how things work. In this case, women are forced to make hard decisions, because the inflexible conditions do not give them other options. This is the moment when many give up. And contrary to what is widespread, not because they want, but because they see no alternatives.

Haynes (2008) observes how these issues are linked to the control of the female body. The body is perceived as "an integral component of the human agency, it is a central concern of personal identity, and it relates to the structure and functioning of organizations." For the researcher, "the body becomes a medium for the exhibition of accordance, or indeed non-accordance, to social norms, which affects our embodied practices, emotions and identities." It is interesting to note that this dilemma is highly feminine, due to different factors: it goes from the image that society built of the woman, which is an image linked to the mother's role, and not mothers, and all the related charges. The author registers the tendency of the body to be seen as an entity that is in the process of turning into a project that must be worked on and carried out as part of an individual self-identity." This issue returns to the agenda later on.

One of the main results of this construction is the idea that there are roles predominantly feminine. That is, everything concerning care, for example, is seen as a "natural vocation" of women. Therefore, man is the reference as provider, which is a contradiction, given that data from the last IBGE census, in 2000 show that women headed 24.9 percent of the 44.8 million homes. In 2010, 38.7 percent of the 57.3 million registered households were led by women who lived without a husband or partner, raising their children alone. From 2004 to 2014, there was a 67 percent increase in the number of homes run by women.

In addition to the process of keeping stereotypes and inequalities, last April, a popular national magazine published an edition whose cover described the current president's wife as "beautiful, discreet and dedicated to home care." These terms strengthen the current male chauvinism attitude by describing the desirable woman as one with a "perfect" body, always "tidy" and available to the man, that is, "protected" inside her home. These are words that go in the opposite direction of the few perceived advances and ways of humanity progress.

For example, in large companies, considered as references for everyone who wants to work, people arrive very early and leave late. Therefore, it is a model incompatible with the ideas mentioned in the previous paragraph, and also incompatible with a good and high-quality private life for women, considering their double or triple journeys. At this point, we should make a wide reflection on choices and absence of options for making decisions about being in the labor market.

\section{Dysfunctions and unequal distribution of domestic tasks}

A latent problem related to this context is to understand why it is still so difficult to think about the possibility of spouses taking up domestic activities or at least distributing them more equitably, especially if the woman has achieved a better professional position. 
When this occurs spontaneously, it means that the family decided to act out of the imposed standards, and such attitudes tend to be questioned by family, friends and colleagues. The described behavior leads us to conclude that, in terms of the distribution of domestic tasks, there seems to be a complicity of the society, so that men can be more available for professional opportunities. That is, the structure stimulates the permanence of the status quo.

Many variables demonstrate the complexity of this discussion. It is also necessary to consider the large number of people that must be involved in order to make behavior changes, to deconstruct many consolidated ideas that support the male chauvinist and racist order that prevails in the country. This can lead to the extreme case of the woman herself reproducing male chauvinist speeches and attitudes, since the "truths" are internalized, always having the white man as a universal reference for good and correct.

This discussion gains embodied biases and additional layers of prejudice when it comes to black women, that is, when the racial issue is added, as discussed below. Bento (2017) states: "At a time when companies outside Brazil measure the positive impact of race and gender diversity on their leadership, there is still passivity and silence over the strong exclusion of black women from top management positions in large corporations in Brazil."

\section{Black women: the base of the pyramid of inequalities}

It is a fact that the participation of black women in the labor market has increased. However, it is necessary to assess under which conditions this growth occurred and where black women are professionally allocated. According to a study by the Instituto Ethos (2017), black women remain under-represented (0.6 percent), besides having the lowest employability rate.

Based on data compilation from several research institutes, like the Inter-Union Department of Statistics and Socio-economic Studies, the State System of Data Analysis Foundation, IBGE and IPEA, it is possible to verify situations such as: the black woman's average wage is still half of the white woman's. The black female worker enters the labor market earlier and is the last to leave it. According to data from the Annual List of Social Information, published in 2012 by the Ministry of Labor and Employment, there are 498,521 black women's formal jobs, against 7.6 million of white women and 11.9 million of white men. In addition, the black woman earns, on average, $\mathrm{R} \$ 790$, while the white man's salary reaches $\mathrm{R} \$ 1,671$ - more than double.

Even with an educational level similar to that of white women, the wage is about 40 percent higher for the latter. The earnings of black women compared to white men, of the same educational levels, do not exceed 53 percent.

Black women have a higher unemployment rate anywhere in the country, and for black girls, it is as high as 25 percent. Of these, one in four young people is unemployed; and black women are more present in the most precarious jobs -71 percent of black women are in precarious and informal works, against 54 percent of white women and 48 percent of white men.

We should also reflect on the notion of care as a "natural" vocation of women. And, more precisely, the responsibility attributed to black women - still a trace of the slavery period. The fact is that in order for women to go out to work, they must delegate "their household duties" - the tasks related to care, either with the home or with family members. This means that, once again, the poorest women - mostly black women - will be punished. These are the women who will sometimes work in precarious conditions, giving up raising or being with their children and family.

Kim (2004) argues that "social stereotypes and discrimination against minority groups have been the most commonly used means of relegating them to a situation of inferior jobs." For the researcher, ethnic minorities and women are considered as intellectually 
REGE 25,1 inferior and incapable of being people in circulation. People from this population group are considered as emotionally dependent, immature and sexually threatening. Thus, Silva et al. (2016) observe that speaking of equalitarian conditions in Brazil goes beyond the formal aspects of civil rights, since many historical facts prove the iniquity suffered, especially by the black population.

Thus, we can conclude that beyond the different discriminatory attitudes, an important part of black women's difficulties of access is especially related to the extended period of explicit enslavement that the black population, and particularly black women, suffer at present, which we can call late development and education (when it happens!). Among other consequences, they still have lower levels of education. There seems to be a pact of silence and omission regarding such adversity.

In addition, once they are able to overcome the barriers and have access to the labor market, black women will face a racist society, which will require of them the constant confirmation of their capacity to be there, and that there was no mistake in being hired; that "it paid off" for the company not to choose a non-black person for that job at the time of the selection. Thus, building a professional path for black women is an exercise that demands enormous portions of resilience, perseverance, and endurance.

Given the conditions shown above, it is possible to point black women as occupying the last spot in the social scale because they are unequally burdened by the disadvantages of the Brazilian system, which is structured in an unfair and racist way.

\section{Who assumes the questioning for equal conditions?}

Women make up the majority of the Brazilian population and account for more than 40 percent of the workforce outside the home. However, they remain invisible in the public area. The United Nations (UN) Women, in partnership with the Inter-Parliamentary Union, launched last March an overview on the political participation of women in the world. According to the UN website (2017), of the 174 countries analyzed, Brazil, with only one minister, is at the 167th place in the world ranking of women's participation in the Executive. Regarding the ranking of participation in the Congress, "the country was at the 154th place, with 55 of the 513 seats of the House of Representatives occupied by women, as well as 12 of the 81 seats of the Senate."

It is mandatory to create conditions for a more balanced and humane look at women, as well as to sensitize and guide boys and men toward full respect for them.

\section{Propositions and future questions}

The topic of diversity is being introduced in the curriculum of many schools. Therefore, a few disciplines have brought this discussion to the classroom. Students, in turn, have started the debate in different spaces. Collectives, bloggers and YouTubers have gained a lot of visibility. In addition, with a large offer of disciplines and related events, it is possible to name situations and point out themes that lack a broad discussion, especially at home. This has guided the new generations toward other practices and more collaborative coexistence.

Few organizations have already started a timid inclusion movement, with the establishment of quotas for women. To do this, departments are being structured to reflect about diversity in the professional space and even offer conditions more suitable to the reality of women. However, the wider movement still goes in the opposite direction, as demonstrated earlier.

Hence, discussions on quotas for women in organizations should be expanded, in order to deconstruct misconceptions about reservation of job vacancies. According to Lucas (2015), in the process of fostering fairer conditions for career access and progress, human resources' professionals can play a key role, since they can plan the adoption of practices that address the inequalities and perversities imposed by organizations. 
It is necessary to create mechanisms to ensure the legitimacy to speak for all women, since there are specificities that need to be more broadly discussed. This applies not only to black women, as in the roundtable that originated this pensata, but also to native women, "quilombolas" and gypsies, among others.

In Brazil, a country acknowledged for being male chauvinist, it is imperative to develop strategies to demonstrate that the performance of domestic tasks is not related to gender. It seems simplistic to propose something on these terms. However, the double and even triple working journey, in addition to the issues previously mentioned, brings guilt and fatigue. According to Bourdieu (2005, p. 108), "[...] the daughters of working mothers have higher career aspirations and are less attached to the traditional model of female condition." That is, representation can open routes to cope with unequal conditions between genders.

Given this scenario, the gap of specific public policies to assist women's issues, such as day care centers, laundries and public restaurants, will remain for many years. This should change with more women in politics struggling for equal life conditions.

All the discussion about social markers that establish the difference, and with it the exclusion, must cross the academic borders and influence the local, or perhaps the global, business community. It should sensitize them toward the imperative need to review prejudiced methods and procedures that are crystallized in companies, due to the banalization of pernicious actions and attitudes that were and continue to be "natural." This mobilization should start at home.

\section{References}

Bento, C. (2017), "Gênero e raça: o desafio das empresas brasileiras", available at: www.cartacapital. com.br/economia/genero-e-raca-o-desafio-das-empresas-brasileiras

Bourdieu, P. (2005), A dominação masculina, 4a ed., Bertrand Brasil, Rio de Janeiro.

Grant Thornton Brasil (2017), "Maioria das empresas brasileiras não têm mulheres em cargos de liderança", available at: www.grantthornton.com.br/press-releases/imprensa/ women-in-business/

Haynes, K. (2008), "(Re)figuring accounting and maternal bodies: the gendered embodiment of accounting professionals", Accounting, Organizations and Society, Vol. 33 Nos 4/5, pp. 328-348.

Instituto de Pesquisa Econômica Aplicada (IPEA) (2011), Retrato das desigualdades de gênero e raça/Instituto de Pesquisa Economica Aplicada et al., ISBN: 857811122-2, 4a ed., IPEA, Brasília, 39pp.

Instituto Ethos (2017), "Perfil Social, Racial e de Gênero das 500 maiores empresas do Brasil e suas ações afirmativas", available at: www3.ethos.org.br/cedoc/perfil-social-racial-e-de-genero-das500-maiores-empresas-do-brasil-e-suas-acoes-afirmativas/\#.WcQXfvOGPIU

Kim, S.N. (2004), "Racialized gendering on the accountancy profession: toward an understanding of Chinese women's experiences in accountancy in New Zealand", Critical Perspectives on Accounting, Vol. 15 No. 3, pp. 400-428.

Lombardi, M.R. (2017), "Engenheiras na construção civil: a feminização possível e a discriminação de gênero", Cadernos de Pesquisa, Vol. 47 No. 163, pp. 122-146, doi: 10.1590/198053143619.

Lucas, A.C. (2015), "Justiça organizacional de gênero nas empresas: os sentidos atribuídos pelos profissionais de recursos humanos", Tese (Doutorado em Administração) - Faculdade de Economia, Administração e Contabilidade, Universidade de São Paulo, São Paulo.

Silva, S.M.C., Casa Nova, S.P.C. and Carter, D.B. (2016), "Brazil, racial democracy? The plight of Afro-descendent women in political spaces", in Lehman, C. (Ed.), Accounting in Conflict: Globalization, Gender, Race and Class, Book Series: Advances in Public Interest Accounting, ISBN: 978-1-78560-976-3, Vol. 19, Emerald Group Publishing Limited, pp. 29-55. 
REGE

25,1

8

\section{Further reading}

Nações Unidas no Brasil (2017), "Brasil fica em $167^{\circ}$ lugar em ranking de participação de mulheres no Executivo, alerta ONU”, available at: https://nacoesunidas.org/brasil-fica-em-167o-lugar-emranking-de-participacao-de-mulheres-no-executivo-alerta-onu/ (accessed September 21, 2017).

\section{About the authors}

Sandra Maria Cerqueira da Silva was a former PhD Student in Accounting at the FEA/USP. Her PhD thesis was entitled "Glass Ceilings: gender and race in Accounting in Brazil." She is currently a Professor at the Feira de Santana State University and Anísio Teixeira College. Sandra Maria Cerqueira da Silva is the corresponding author and can be contacted at: mestsandra@gmail.com

Angela Lucas was a former undergraduate, MSc and $\mathrm{PhD}$ Student in Administration at the FEA/USP. Her PhD thesis was entitled "Gender organizational justice in companies: the meanings attributed by human resources professionals." She is currently a Professor at the FEI.

For instructions on how to order reprints of this article, please visit our website: 